\title{
The bistable network model of brain ischemia
}

\author{
Konstantin-A. Hossmann, M.D., Ph.D. \\ Director emeritus of Max Planck Institute for Neurological Research, Gleueler Strasse 50, D-50931 Köln, Germany
}

\begin{abstract}
In a set of four interconnected papers DeGracia presents a novel network-based explanatory framework for conceptualizing the outcome of ischemic injury that deviates sharply from the currently prevailing approach of linear injury superposition. The thorough analysis of the increasing use of network theory in modern biology provides the background for envisioning a new chapter of brain ischemia research which may be able to overcome the present dilemma of stroke treatment.
\end{abstract}

Keywords: Bistable network model; brain ischemia.

According to the most recent statistics of the American Heart Association, stroke accounts for about one for every 17 deaths in the United States (Lloyd-Jones et al 2009). With the growth of the elderly population, the prevalence and the costs of stroke steadily increase, and there is general consent that efficient therapeutic strategies are urgently needed to cope with this alarming situation. The scientific community and the agencies responsible for the funding of stroke research have responded in the appropriate way, and the number of research reports dealing with stroke or brain ischemia amount to well over 8000 publications per year. However, up to now the combined effort of this research had little effect, at least as far as the efficiency of stroke therapy is concerned. Although over 1000 mostly successful experimental treatments have been reported (O'Collins et al 2006), evidence-based clinical improvements are sparse. So far, the only Food and Drug Administration (FDA)approved stroke treatment is recombinant tissue plasminogen activator (rtPA)-induced thrombolysis within 3 hours of stroke onset but none of the many molecular neuroprotective interventions provided significant improvement in randomized double-blind class III trials. To deal with this problem, stroke research recommendations have been established in the Unites States (Fisher et al 2009) and the European Community (Meairs et al 2006). However, even strict adherence to these guidelines did not improve clinical outcome, as dramatically exemplified by the failure of the NXY-059 (SAINT II) trial (Shuaib et al 2007). The therapeutic dilemma that "all drugs work in animals but not in patients" has, therefore, been criticized repeatedly over the past decades.
In a remarkable series of four interconnected papers published in this issue of the Journal of Experimental Stroke and Translational Medicine (DeGracia 2010ad) DeGracia concludes that "something is fundamentally wrong with the current conception of ischemic brain injury". Based on the analysis of the reasons and consequences of this failure he formulates a Boolean networks-based view of brain ischemia which provides the theoretical background of a new explanatory framework for the understanding of ischemic brain injury and its therapeutic implications. It is not an easy task to condense this impressive treatise to an easily understandable message which can be summarized in a few sentences. To me, two important statements stand out: (1) The enormous number of mutually interacting disease-relevant processes associated with brain ischemia can be categorized into just two classes, a class of damage and a class of protection which according to DeGracia is the stress response; and (2) the final outcome of a brain cell exposed to ischemia is bimodal, i.e. life or death. The trajectory by which brain cells move towards either outcome is dependent on their relative position in a multidimensional network in which cell damaging and cell protective influences interact to form a network space state through which these trajectories run.

The picture DeGracia chooses to visualize this concept is a multifolded landscape with heights and valleys in which life and death are the deepest parts to which the fate of the cell - represented by a downwards rolling marble ball - is attracted. As simple as this concept may appear on first sight, it accounts for the full complexity of ischemic injury. The more se-

\section{* Correspondence should be sent to:}

Konstantin-A. Hossmann, M.D., Ph.D., Director emeritus of Max Planck Institute for Neurological Research, Gleueler Strasse 50, D-50931 Köln

Germany. Tel. +49 (0)221 4726 219/212; Email: hossmann@nf.mpg.de

Copyright $\odot 2010$ SFES 1939-067X/10 
vere the ischemic impact - DeGracia calls it the "amount" of ischemia - the higher the marble ball is lifted from the valley of life to the mountains of ischemic injury, and the closer it comes to the inclination point between life and death, the higher is the risk that it will roll towards the valley of death and not back to life. Successful therapy, in this system, is the right kick to move the marble ball over the inclination point towards the valley of life. The trajectory the ball may follow to roll down is variable but formally of little importance because there are only two outcomes, life or death.

In ischemia research the idea of a struggle between life and death was first brought up by Igor Klatzo who called it the "battle for survival" (Klatzo and Spatz 1981). To explain the pathophysiology of this battle he went back to Cecile and Oscar Vogt and their concept of pathoclisis (Vogt and Vogt 1925). According to this concept certain cell populations such as the selectively vulnerable $\mathrm{CA}_{1}$ neurons of hippocampus are particularly endangered to succumb because of their inborn sensitivity to ischemic injury. But as this struggle goes on for some time until the fate of the cell has been determined, non-surviving cells undergo delayed rather than immediate death.

DeGracia advances this concept a big step ahead. He postulates that, in principle, the struggle between life and death applies to all cells of the brain and more important - that it can be modelled and eventually solved by differential equations and Boolean algebra. Obviously, this is a long way to go. DeGracia, therefore, cautiously describes his approach as a first step "towards" this view of brain ischemia. But already at its presents state, the model provides good arguments that the prevailing theory of ischemic damage, the so-called ischemic cascade, is basically unsuitable to understand the mechanisms and, hence, the therapeutic implications of ischemic brain damage.

The argument is as follows. According to DeGracia, the "ischemic cascade" is a reductionistic system of superposed linear injury pathways which is best visualized by Wieloch's sandwich model of ischemic injury. In this model the combined injuries add to a "sandwich" of pathological influences that result in irreversible damage whenever the height of the sandwich exceeds the threshold of cell viability. The bistable network model, in contrast, is a non-linear Boolean system which depends on the mutual interactions of all disease-relevant alterations and the outcome of which cannot be predicted by superposition of the individual injury pathways.

I confess that I am sympathetic with DeGracia's criticism of the ischemic cascade because many of the putative injury mechanisms are based on unproven assumptions. An example is glutamate toxicity which - at the concentration and in the context of the other biochemical alterations induced by ischemia in vivo is very unlikely to cause ischemic cell death. Similarly, many therapeutic interventions designed to interfere with the ischemic cascade have never been properly validated. Examples are the unproven assumption that under ischemic conditions which replicate the clinical situation of stroke calcium antagonists are able to reduce cellular calcium flooding, or that inhibitors of water or sodium channels are able to prevent ischemic cell swelling.

However, to relieve the "translational roadblock" (Endres et al 2008) of stroke therapy, network analysis alone is not the solution. An equally important aspect is the appropriateness of the experimental models for the collection of preclinical data that are to be translated to the clinical setting. A frequently encountered misconception of preclinical stroke research is the mix-up of different pathophysiologies of brain ischemia. At least three such pathophysiologies can be clearly distinguished: (1) primary ischemic cell death caused by a reduction of blood flow below the threshold of energy failure; (2) expansion of primary ischemic injury caused by the gradual timedependent increase in the threshold of energy failure; and (3) delayed ischemic cell death caused by molecular disturbances following transient ischemia. Primary energy failure is the dominant pathomechanism of ischemic brain infarction under conditions of permanent or prolonged focal ischemia; the progression of energy failure is responsible for the growth of brain infarcts into the peri-infarct penumbra; and delayed ischemic injury evolves after reversible energy failure, as after brief cardiac arrest. As the mechanisms and the therapeutic windows greatly differ in each of these pathophysiologies, selection of the wrong model will result in inappropriate translation and therapeutic failure (Hossmann 2009). Obviously, this cannot be overcome by improvements of analytical methods but requires adaptation of the experimental model to the actual clinical situation.

Regarding the here presented analysis, the network view of ischemia/reperfusion models a brief cardiac arrest-type of brain injury, i.e. a reversible breakdown of energy metabolism, followed by a delayed type of secondary molecular injury. This is different from ischemic stroke where the primary thresholddependent breakdown of energy metabolism is not reversed and where the final volume of the brain infarct depends on the expansion of energy failure into the peri-infarct penumbra. It would be of paramount importance to adapt the presently proposed network analysis to an experimental model which replicates this pathophysiology and to use the analysis for the prediction of appropriate stroke therapies. 
Dr. DeGracia can be complimented for envisioning this novel approach to analyse and possibly understand the complexity of ischemic brain injury. For the medical readership his four interconnected papers which cover a wide spectrum of conceptual and analytical aspects of brain ischemia are demanding. But the time spent to appreciate his profound thoughts will be of great benefit to all who are interested in this field of research, and particularly to those who have not given up searching for a solution to the present dilemma of clinical stroke therapy.

\section{Conflict of interest}

None

\section{References}

DeGracia DJ (2010a) Towards a dynamical network view of brain ischemia and reperfusion. Part I: Background and preliminaries. Journal of Experimental Stroke and Translational Medicine $\mathrm{xx}: \mathrm{xx}-\mathrm{xx}$

DeGracia DJ (2010b) Towards a dynamical network view of brain ischemia and reperfusion. Part II: Post-ischemic neuronal state space. Journal of Experimental Stroke and Translational Medicine $\mathrm{xx}: \mathrm{xx}-\mathrm{xx}$

DeGracia DJ (2010c) Towards a dynamical network view of brain ischemia and reperfusion. Part III: Therapeutic implications. Journal of Experimental Stroke and Translational Medicine xx:xx-xx

DeGracia DJ (2010d) Towards a dynamical network view of brain ischemia and reperfusion. Part IV: Additional considerations. Journal of Experimental Stroke and Translational Medicine $\mathrm{xx}: \mathrm{XX}-\mathrm{Xx}$

Endres M, Engelhardt B, Koistinaho J, Lindvall O, Meairs S, Mohr JP, Planas A, Rothwell N, Schwaninger M, Schwab ME, Vivien D, Wieloch T, Dirnagl U (2008) Improving outcome after stroke: Overcoming the translational roadblock. CerebrovascDis 25:268-78
Fisher M, Feuerstein G, Howells DW, Hurn PD, Kent TA, Savitz SI, Lo EH (2009) Update of the Stroke Therapy Academic Industry Roundtable preclinical recommendations. Stroke 40:2244-50

Hossmann K-A (2009) Pathophysiological basis of translational stroke research. Folia Neuropathol 47:213-27.

Klatzo I, Spatz M (1981) Cerebral ischaemia. In: Molecular Basis of Neuropathology (Davison AN, Thompson RHS, eds): Edward Arnold, London, 132-49

Lloyd-Jones D, Adams R, Carnethon M, De Simone G, Ferguson $\mathrm{T}$, Flegal $\mathrm{K}$, Ford $\mathrm{E}$, Furie $\mathrm{K}$, Go A, Greenlund K (2009) Heart disease and stroke statistics--2009 update. A report from the American Heart Association Statistics Committee and Stroke Statistics Subcommittee. Circulation 119:e21-e181

Meairs S, Wahlgren N, Dirnagl U, Lindvall O, Rothwell P, Baron JC, Hossmann K, Engelhardt B, Ferro J, McCulloch J, Kaste M, Endres M, Koistinaho J, Planas A, Vivien D, Dijkhuizen $R$, Czlonkowska A, Hagen A, Evans A, De Libero G, Nagy Z, Rastenyte D, Reess J, Davalos A, Lenzi GL, al. e (2006) Stroke research priorities for the next decade - A representative view of the European scientific community - Summary of Stroke Research Workshop, Brussels, October 25, 2005. CerebrovascDis 22:75-82

O'Collins VE, Macleod MR, Donnan GA, Horky LL, van der Worp BH, Howells DW (2006) 1,026 experimental treatments in acute stroke. Annals of Neurology 59:467-77

Shuaib A, Lees KR, Lyden P, Grotta J, Davalos A, Davis SM, Diener H, Ashwood T, Wasiewski WW, Emeribe $U$ (2007) NXY-059 for the treatment of acute ischemic stroke. NEnglJMed 357:562-71

Vogt C, Vogt O (1925) Der Begriff der Pathoklise. J Psychol Neurol 31:245 